Journal of Applied Pharmaceutical Science Vol. 6 (10), pp. 092-097, October, 2016

Available online at http://www.japsonline.com

DOI: $10.7324 / \mathrm{JAPS} .2016 .601012$

ISSN 2231-3354 (cc) BY-NC-SA

\title{
Nitriergic Influence in the Compromised Antidepressant Effect of Fluoxetine in Stressed Mice
}

\author{
Vaibhav Walia, Neeraj Gilhotra* \\ Department of Pharmaceutical Sciences, Maharshi Dayanand University Rohtak-124001, Haryana, India.
}

\section{ARTICLE INFO \\ Article history: \\ Received on: 19/05/2016 \\ Revised on: 30/06/2016 \\ Accepted on: 07/08/2016 \\ Available online: 29/10/2016}

\section{Key words:}

Depression, fluoxetine, immobility, mice, nitric oxide, stress.

\begin{abstract}
Objective: Investigation of possible nitriergic mechanism involved in the compromised antidepressant effect of fluoxetine in stressed mice.

Materials and methods: Male swiss albino mice were used in the present study. Mice were stressed by immobilization of $2 \mathrm{hrs}$. Mice subjected to stress were considered as stressed mice and mice not subjected to stress were considered as unstressed mice. All the treatments were administered intraperitoneally (i.p.) in a fixed volume of $10 \mathrm{ml} / \mathrm{kg}$ and the depression like behavioral alterations in unstressed and stressed mice was measured by TST followed by FST. Nitrite levels were measured in brain homogenates to determine the possible involvement of nitriergic mechanism.

Results: Present study showed that the $2 \mathrm{hrs}$ immobilization significantly increased the immobility period of mice in both TST and FST, with the concurrent increase in the levels of nitrite in the brain of stressed mice as compared to the vehicle treated unstressed mice. Fluoxetine (FLX) $(20 \mathrm{mg} / \mathrm{kg}$, i.p.); pyrrolidine dithiocarbamate (PDTC) $(100 \mathrm{mg} / \mathrm{kg}$, i.p.) and methylene blue (MB) $(100 \mathrm{mg} / \mathrm{kg}$, i.p.) significantly reduced the immobility period of stressed mice in both TST and FST as compared to vehicle treated stressed mice. Pre-treatment with PDTC (100 mg/kg, i.p.) followed by the administration of FLX (20 mg/kg, i.p.) did not significantly alter the immobility period and nitrite levels as compared to the FLX $(20 \mathrm{mg} / \mathrm{kg}$, i.p. $)$ treated stressed mice. Pre-treatment with MB (100 mg/kg, i.p.) followed by the administration of FLX $(20 \mathrm{mg} / \mathrm{kg}$, i.p.) did not significantly alter the immobility period of mice in TST, but significantly reduced the immobility period of mice in FST as compared to the FLX $(20 \mathrm{mg} / \mathrm{kg}$, i.p. $)$ treated stressed mice. Also the pre-treatment with MB $(100 \mathrm{mg} / \mathrm{kg}$, i.p. $)$ followed by the administration of FLX (20 mg/kg, i.p.) significantly reduced the nitrite levels as compared to the FLX (20 $\mathrm{mg} / \mathrm{kg}$, i.p.) treated stressed mice.

Conclusion: It has been concluded that the immobilization stress induced increase production of NO was involved in the compromised antidepressant effect of fluoxetine in stressed mice.
\end{abstract}

\section{INTRODUCTION}

Stress disturbs the physiological homeostasis of body (Bohus et al., 1993) and precipitates mood disorders such as depression (McEwen, 2000). Stress plays a prominent role in the provocation of depression (Caspi et al., 2003) and induces a state analogous to depression (Vollmayr and Henn, 2003). Stress also increase the expression of pro-inflammatory cytokines such as IL-1 $\beta$, IL-6, and TNF- $\alpha$ in the brain of animals exposed to stress (Wichers and Maes, 2002) and IL-6 activates NMDA receptors

* Corresponding Author

Neeraj Gilhotra, Department of Pharmaceutical Sciences, Maharshi Dayanand University Rohtak-124001, Haryana, India. Email: neerajmdu@ rediffmail.com
(Maj et al., 1992; Qiu et al., 1995). Also the stress evokes the release of glutamate in the brain that results in the activation of NMDA receptors (Maj et al., 1992); present in linked with the neuronal nitric oxide synthase (nNOS) (Cheah et al., 2006). Therefore the activation of NMDA receptors is responsible for the increased expression of nNOS; responsible for the production of nitric oxide (NO) (Cheah et al., 2006). The cytokines such as IL-1 and TNF- $\alpha$ increases the expression of NF- $\kappa \beta$ pathway that is responsible for the increase expression of inducible nitric oxide synthase (iNOS) (Cooke et al., 2001; Hua et al., 2008; Alexopoulos and Morimoto, 2011; Madrigal et al., 2002); which once induced continues to produce the larger quantities of NO (Madrigal et al., 2002). 
$\mathrm{NF}-\kappa \beta$ pathway activation also reduced the production of monoamines and neurotrophic factors in the brain (Wuwongse et al., 2010). NO is a unique neurotransmitter, synthesized from Larginine by nitric oxide synthases (NOS) (Garthwaite et al., 1988) in two step process; in first step L-arginine is converted to $\mathrm{N}$ hydoxy-L-arginine, and in the subsequent step N-hydoxy-Larginine is converted into NO and citrulline (Walia et al., 2014). NOS exist in three isoforms: eNOS, iNOS and nNOS with 51-57\% homology between isoforms and different localizations, regulation, catalytic properties and inhibitor sensitivity (Walia et al., 2014; Walia, 2016b).

NO modulates the extracellular levels of serotonin (5HT) (Kaehler et al., 1999). NO inactivate the rate limiting enzyme involved in the synthesis of 5-HT (Kuhn and Arthur, 1996). NO also known to influence release, reuptake and function of 5-HT (Straub et al., 2007). 5-HT is responsible for the regulation of mood and behavior (Rajkumar and Mahesh, 2010) and therefore its deficiency and reduced transmission contribute to depression (Rang et al., 2007).

In laboratory animal depression like behavioral alterations is caused by immobilization stress (Hayase, 2011; Sevgi et al., 2006; Poleszak et al., 2006). Immobilization stress of $2 \mathrm{hrs}$ has been shown to increase the immobility period of mice in both TST and FST (Poleszak et al., 2006; Walia, 2016a). Immobilization of 6hrs increased the levels of nitrite in the rodents exposed to immobilization (Madrigal et al., 2002, Gilhotra et al., 2010; Gilhotra and Dhingra, 2011). Also we have previously described that $2 \mathrm{hrs}$ immobilization influence the antidepressant effect of fluoxetine in mice (Walia, 2016a). Therefore the present study was designed to determine the possible involvement of the nitriergic mechanism in the compromised antidepressant effect of fluoxetine in stressed mice.

\section{MATERIALS AND METHODS}

\section{Animals}

Male swiss albino mice were used in the present study. All the mice were kept under controlled conditions of light and environmental and had free access to food and water. The testing was carried out between 9:00 and 16:00 h. The study protocols were approved by Institutional Animal Ethics Committee (IAEC) and care of the animals was carried out in compliance with the guidelines of the Committee for the Purpose of Control and Supervision of Experiments on Animals (CPCSEA).

\section{Drugs and selection of doses}

Fluoxetine (FLX) (Cadila Pharmaceuticals, Ahmedabad India); Pyrrolidine dithiocarbamate (PDTC) (Loba chemie India) and methylene blue (MB) (Loba chemie India), were used in the present study. The doses were selected on the basis of the relevant previous studies. FLX (20 mg/kg; i.p.) was used as standard antidepressant drug (Conti et al., 2002; Walia, 2016a); MB (100 $\mathrm{mg} / \mathrm{kg}$, i.p.) (Klamer et al., 2004) was used as an inhibitor of NOS and soluble guanylyl cyclase (sGC) (Savegnago et al., 2008) and
PDTC (100 mg/kg, i.p.) (Gilhotra et al., 2010) was used as an inhibitor of NF- $\kappa \beta$ pathway (Madrigal et al., 2002).

\section{Immobilization stress}

Stress was produced by immobilizing the mice for $2 \mathrm{hrs}$ by taping, all its four limbs and trunk against a wooden board (Mazzon and Cuzzocrea, 2008; Walia, 2016a).

\section{Assessment of depression like behavior in mice Tail suspension test (TST)}

In TST, each mouse was individually suspended at a height of $30 \mathrm{~cm}$ from the floor, by adhesive tape placed approximately $1 \mathrm{~cm}$ from the tip of the tail. The total period of immobility was recorded for $6 \mathrm{~min}$. Mouse was considered to be immobile when it did not show any body movement, hung passively and completely immobile (Steru et al., 1985).

\section{Forced swim test (FST)}

In FST, each mouse was individually forced to swim in the open glass chamber containing fresh water to a height of $15 \mathrm{~cm}$ and maintained at $26 \pm 1^{\circ} \mathrm{C}$. Each mouse shows vigorous movements during the initial 2 min period of the test. The duration of immobility was recorded during the next $4 \mathrm{~min}$ of the total 6 min testing period (Porsolt et al., 1977).

\section{Biochemical estimations \\ Nitrite estimation in brain homogenates}

Nitrite estimation was carried out in the brain homogenates of mice. In brief, mice were sacrificed by decapitation; brains were removed, rinsed with isotonic saline and weighed. A $10 \%(\mathrm{w} / \mathrm{v})$ tissue homogenate was prepared with 0.1 $\mathrm{M}$ phosphate buffer ( $\mathrm{pH}$ 7.4). Equal volume of brain homogenate and Greiss reagent $(0.1 \%$ of $\mathrm{N}$-1-napththyl ethylenediamine dihydrochloride, $1 \%$ sulphanilamide and $2.5 \%$ o-phosphoric acid) were mixed, the mixture was incubated for $10 \mathrm{~min}$ at room temperature and absorbance was measured at $540 \mathrm{~nm}$ (Green et al., 1982).

\section{Experimental protocol}

Male swiss albino mice were used in the present study. Stress was produced by immobilizing the mice for $2 \mathrm{hrs}$ (Mazzon and Cuzzocrea, 2008; Walia, 2016a). Mice subjected to stress were considered as stressed mice and mice not subjected to stress were considered as unstressed mice. All the treatments were administered intraperitoneally (i.p.) at a fixed volume of $10 \mathrm{ml} / \mathrm{kg}$. Unstressed mice were administered $30 \mathrm{~min}$ prior to testing whereas the stressed mice were administered immediately before subjecting them to immobilization (Gilhotra and Dhingra, 2011). In case of the pre-treatment or where the combinations of drugs were used, the time elapsed between the two treatments was 10 min. Behavioral testing was started $10 \mathrm{~min}$ after setting the animal free from immobilization. Behavioral testing was performed in stepwise manner i.e. TST followed by FST with 5 min difference between the two testing procedures (Walia, 2016a). Separate 
groups of mice were used for the estimation of nitrite levels in brain. Nitrite was estimated in the brain homogenates by the spectrophotometeric assay based on Greiss reaction (Green et al., 1982). Nitrite concentration in supernatant was determined from nitrite standard curve and expressed in $\mu \mathrm{M}$.

\section{Statistical analysis}

Data were analyzed by one-way analysis of variance (ANOVA) followed by Tukey's post hoc test. Values were expressed as Mean \pm S.E.M. and $\mathrm{p}<0.05$ was considered as statistically significant.

\section{RESULTS}

\section{Effect of different treatment on the immobility period of mice in TST and FST}

Effect of different treatments on the immobility period of unstressed and stressed mice in TST and FST was shown in the fig. 1 and fig. 2. In the present study immobilization stress of $2 \mathrm{hrs}$ significantly enhanced the immobility period of mice in both TST and FST as compared to the vehicle treated unstressed mice. Administration of FLX (20 mg/kg, i.p.) to the unstressed mice reduced the immobility period in both TST and FST significantly as compared to vehicle treated unstressed mice. Administration of FLX (20 mg/kg, i.p.) to the stressed mice reduced the immobility period in both TST and FST significantly as compared to vehicle treated stressed mice.

Also there was a significant difference in the immobility period of FLX (20 mg/kg, i.p.) treated unstressed mice and FLX (20 mg/kg, i.p.) treated stressed mice in both TST and FST. Administration of PDTC (100 mg/kg, i.p.) to stressed mice significantly reduced the immobility period in both TST and FST as compared to vehicle treated stressed mice. Pre-treatment with PDTC (100 mg/kg, i.p.) followed by the administration of FLX (20 $\mathrm{mg} / \mathrm{kg}$, i.p.) to the stressed mice significantly reduced the immobility period in TST as compared to vehicle treated stressed mice. However the pre-treatment with PDTC $(100 \mathrm{mg} / \mathrm{kg}$, i.p.) followed by the administration of FLX (20 mg/kg, i.p.) to the stressed mice did not significantly influence the immobility period of stressed mice in both TST and FST as compared to the FLX (20 $\mathrm{mg} / \mathrm{kg}$, i.p.) treated stressed mice. Also the combine treatment with PDTC (100 mg/kg, i.p.) and FLX (20 mg/kg, i.p.) to the stressed mice results in the death of all the 5 mice after TST. Administration of $\mathrm{MB}(100 \mathrm{mg} / \mathrm{kg}$, i.p.) to the stressed mice reduced the immobility period in both TST and FST significantly as compared to vehicle treated stressed mice. Also the administration of $\mathrm{MB}(100 \mathrm{mg} / \mathrm{kg}$, i.p.) to the stressed mice significantly reduced the immobility period in FST as compared to FLX (20 mg/kg, i.p.) treated stressed mice. Pre-treatment with MB (100 $\mathrm{mg} / \mathrm{kg}$, i.p.) followed by the administration of FLX (20 $\mathrm{mg} / \mathrm{kg}$, i.p.) reduced the immobility period in both TST and FST significantly as compared to vehicle treated stressed mice. However the pre-treatment with MB $(100 \mathrm{mg} / \mathrm{kg}$, i.p.) followed by the administration of FLX $(20 \mathrm{mg} / \mathrm{kg}$, i.p.) reduced the immobility period in FST only significantly as compared to FLX $(20 \mathrm{mg} / \mathrm{kg}$, i.p.) treated stressed mice.

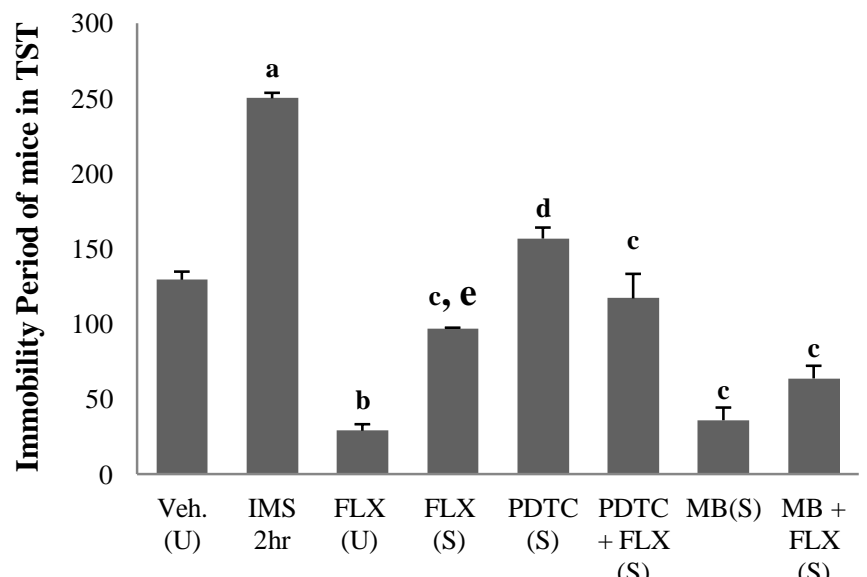

Fig.1. Effect of different treatments on immobility period of mice in TST. $\mathrm{n}=5$ in each group. Values expressed as the mean \pm SEM. Data were analyzed by ANOVA followed by Tukey's post-hoc test, $F(7,32)=54.458 . a=p<0.001$ significant difference from the vehicle treated unstressed mice; $b=p<0.01$ significant difference from the vehicle treated unstressed mice; $c=p<0.001$ significant difference from vehicle treated stressed mice; $d=p<0.05$ significant difference from vehicle treated stressed mice; $e=p<0.001$ significant difference from FLX treated unstressed mice. Veh $(\mathbf{U})$ : Vehicle treated unstressed mice; IMS 2hr: Vehicle treated stressed mice; FLX (U): Fluoxetine $(20 \mathrm{mg} / \mathrm{kg}$, i.p.) treated unstressed mice; FLX (S): Fluoxetine $(20 \mathrm{mg} / \mathrm{kg}$, i.p.) treated stressed mice; PDTC (S): Pyrrolidine dithiocarbamate $(100 \mathrm{mg} / \mathrm{kg}$, i.p.) treated stressed mice; PDTC + FLX (S): Pyrrolidine dithiocarbamate $(100 \mathrm{mg} / \mathrm{kg}$, i.p. $)$ and fluoxetine (20 mg/kg, i.p.) treated stressed mice; MB (S): Methylene blue (100 $\mathrm{mg} / \mathrm{kg}$, i.p.) treated stressed mice; MB + FLX (S): Methylene blue $(100 \mathrm{mg} / \mathrm{kg}$, i.p.) and fluoxetine $(20 \mathrm{mg} / \mathrm{kg}$, i.p.) treated stressed mice. Doses were mentioned in $\mathrm{mg} / \mathrm{kg}$.

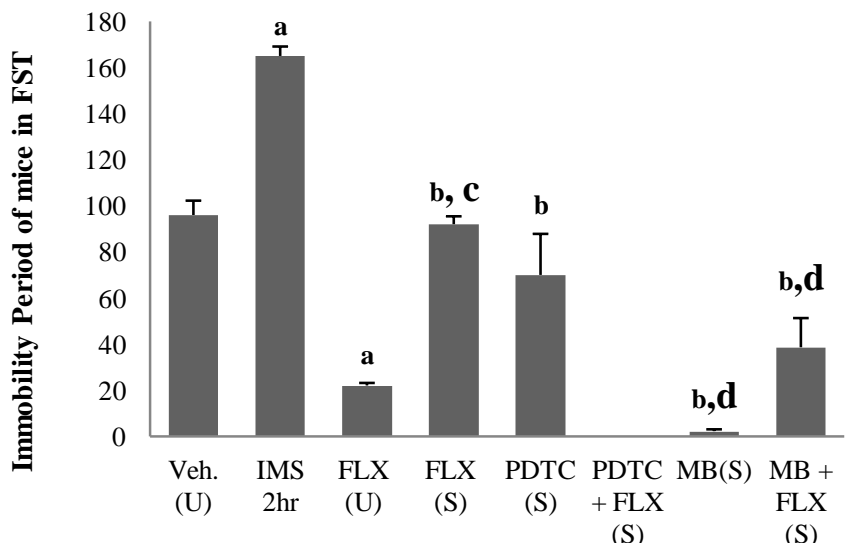

Fig. 2. Effect of different treatments on immobility period of mice in FST. $\mathrm{n}=$ 5 in each group. Values expressed as the mean \pm SEM. Data were analyzed by ANOVA followed by Tukey's post-hoc test, $F(6,28)=61.102$. $a=p<0.001$ significant difference from the vehicle treated unstressed mice; $b=p<0.001$ significant difference from vehicle treated stressed mice; $c=p<0.001$ significant difference from FLX treated unstressed mice; $d=p<0.001$ significant difference from FLX treated stressed mice. Veh (U): Vehicle treated unstressed mice; IMS 2hr: Vehicle treated stressed mice; FLX (U): Fluoxetine $(20 \mathrm{mg} / \mathrm{kg}$, i.p.) treated unstressed mice; FLX (S): Fluoxetine $(20$ $\mathrm{mg} / \mathrm{kg}$, i.p.) treated stressed mice; PDTC (S): Pyrrolidine dithiocarbamate (100 $\mathrm{mg} / \mathrm{kg}$, i.p.) treated stressed mice; PDTC + FLX (S): Pyrrolidine dithiocarbamate $(100 \mathrm{mg} / \mathrm{kg}$, i.p.) and fluoxetine $(20 \mathrm{mg} / \mathrm{kg}$, i.p. $)$ treated stressed mice; MB (S): Methylene blue $(100 \mathrm{mg} / \mathrm{kg}$, i.p.) treated stressed mice; MB + FLX (S): Methylene blue $(100 \mathrm{mg} / \mathrm{kg}$, i.p. $)$ and fluoxetine $(20 \mathrm{mg} / \mathrm{kg}$, i.p.) treated stressed mice. Doses were mentioned in $\mathrm{mg} / \mathrm{kg}$. 


\section{Effect of different treatment on Nitrite levels}

Effect of different treatments on the nitrite levels in the brain of mice was shown in fig. 3. Immobilization stress of $2 \mathrm{hrs}$ enhanced the levels of nitrite in the brain of mice significantly as compared to the vehicle treated unstressed mice. Administration of FLX (20 mg/kg, i.p.) to unstressed mice reduced the nitrite levels significantly as compared to the vehicle treated unstressed mice. Administration of FLX (20 mg/kg, i.p.) to the stressed mice reduced the nitrite levels significantly as compared to the vehicle treated stressed mice. Pre-treatment with PDTC (100 mg/kg, i.p.) followed by the administration of FLX ( $20 \mathrm{mg} / \mathrm{kg}$, i.p.) to stressed mice significantly reduced the nitrite levels as compare to the vehicle treated stressed mice. Pre-treatment with MB $(100 \mathrm{mg} / \mathrm{kg}$, i.p.) followed by the administration of FLX $(20 \mathrm{mg} / \mathrm{kg}$, i.p.) to the stressed mice significantly reduced the nitrite levels as compared to the vehicle and FLX $(20 \mathrm{mg} / \mathrm{kg}$, i.p.) treated stressed mice.

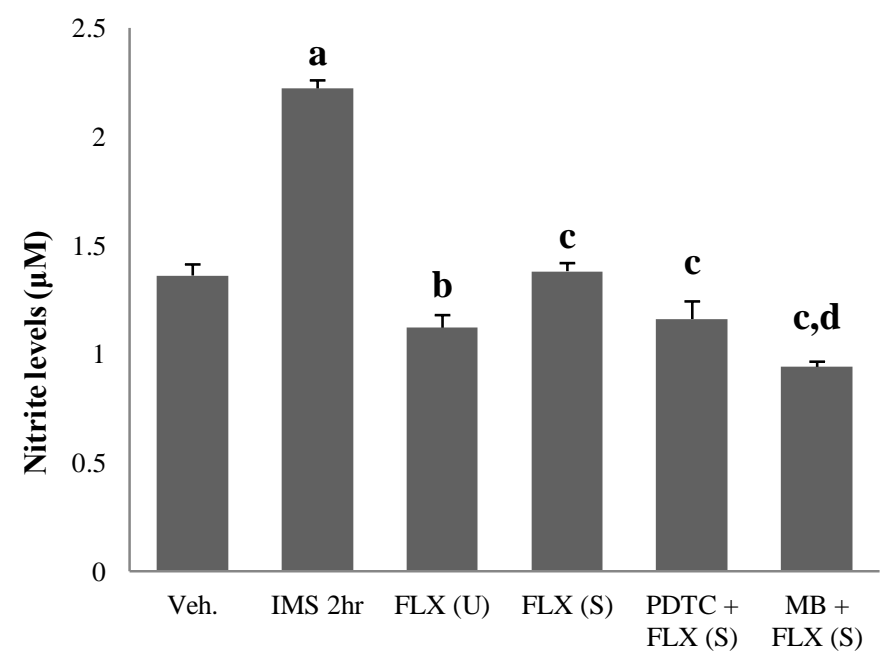

Fig.3. Effect of different treatments on nitrite levels in the brain homogenates of mice. $\mathrm{n}=5$ in each group. Values expressed as the mean \pm SEM. Data were analyzed by ANOVA followed by Tukey's post-hoc test, $\mathrm{F}(5,24)=76.045$. $\mathrm{a}=$ $\mathrm{p}<0.001$ significant difference from the vehicle treated unstressed mice; $b=$ $\mathrm{p}<0.05$ significant difference from the vehicle treated unstressed mice; $c=$ $\mathrm{p}<0.001$ significant difference from the vehicle treated stressed mice; $d=$ $\mathrm{p}<0.001$ significant difference from the FLX treated stressed mice. Veh (U): Vehicle treated unstressed mice; IMS 2hr: Vehicle treated stressed mice; FLX (U): Fluoxetine (20 mg/kg, i.p.) treated unstressed mice; FLX (S): Fluoxetine $(20 \mathrm{mg} / \mathrm{kg}$, i.p.) treated stressed mice; PDTC (S): Pyrrolidine dithiocarbamate $(100 \mathrm{mg} / \mathrm{kg}$, i.p.) treated stressed mice; PDTC + FLX (S): Pyrrolidine dithiocarbamate $(100 \mathrm{mg} / \mathrm{kg}$, i.p.) and fluoxetine $(20 \mathrm{mg} / \mathrm{kg}$, i.p. $)$ treated stressed mice; MB (S): Methylene blue (100 mg/kg, i.p.) treated stressed mice; MB + FLX (S): Methylene blue (100 mg/kg, i.p.) and fluoxetine $(20 \mathrm{mg} / \mathrm{kg}$, i.p.) treated stressed mice. Doses were mentioned in $\mathrm{mg} / \mathrm{kg}$.

\section{DISCUSSION}

Depression is a psychiatric disorder characterized by depressed mood, anhedonia, loss of energy, and low self esteem (Wong and Licinio, 2004). Stress produces alterations in neurotransmitters and neuroendocrine systems (McIntyre et al., 1999; Konstandi et al., 2000) and plays a key role in the pathogenesis of depression (Caspi et al., 2003; Paykel, 2001). Exposure of rodents to uncontrollable stressors in unpredictable manner induces depressive behavior (Willner et al., 1987). Stressinduced depression like behavioral alterations can be assessed by using TST and FST in rodents. Immobility period in TST and FST reflects the behavioral despair, a condition similar to depression in human (Cryan et al., 2005a;b; Steru et al., 1985; Willner, 1984). The present study showed that the exposure of mice to the immobilization stress of $2 \mathrm{hrs}$ significantly increased the immobility period of mice in both TST and FST as shown in fig. 1 and 2. Thus it is established that the immobilization of $2 \mathrm{hrs}$ enhanced the depression or produces acute depression in the mice exposed to immobilization stress of $2 \mathrm{hrs}$. The similar findings had been reported previously also (Poleszak et al., 2006; Walia 2016a). Stressors such as immobilization stress induced depression like behavioral alterations in the rodents (Hayase, 2011; Sevgi et al., 2006; Poleszak et al., 2006). Immobilization stress of $6 \mathrm{hrs}$ increased the levels of nitrite in the rodents exposed to immobilization (Madrigal et al., 2002, Gilhotra et al., 2010; Gilhotra and Dhingra, 2011). The present study showed that the immobilization of $2 \mathrm{hrs}$ significantly increased the nitrite levels in the brain of the mice exposed to the stressed as compare to the unstressed mice. It is therefore suggested that the $2 \mathrm{hrs}$ immobilization stress induced the production of NO in the brain of the mice exposed to the immobilization and the increased production of the NO may be responsible enhancement of depression like behavioral alterations in mice. Fluoxetine, a standard antidepressant drug; belongs to the category of SSRIs and reduces the immobility period of mice in both TST and FST (Walia, 2016a; Cryan et al., 2005a; 2005b). Also in the present study, FLX (20 mg/kg, i.p.) reduced the immobility period of both unstressed and stressed mice significantly as compared to their respective controls as shown in fig. 1 and 2. FLX (20 mg/kg, i.p.) reduced the nitrite levels significantly both in the unstressed and stressed mice with respect to their respective control as shown in fig. 3. However the immobility period of FLX $(20 \mathrm{mg} / \mathrm{kg}$, i.p.) stressed mice is significantly higher as compared to FLX (20 $\mathrm{mg} / \mathrm{kg}$, i.p.) treated unstressed mice as shown in fig.1, 2 and 3. Therefore the increased levels of the nitrite in the brain of FLX (20 $\mathrm{mg} / \mathrm{kg}$, i.p.) treated stressed mice compromised the antidepressant effect of FLX $(20 \mathrm{mg} / \mathrm{kg}$, i.p. $)$ in stressed mice and therefore responsible for the higher immobility period as compared to the FLX $(20 \mathrm{mg} / \mathrm{kg}$, i.p.) treated unstressed mice.

Several mechanisms had been proposed by which stress increased the levels of NO in the brain. It has been suggested that the stress results in the release of glutamate in the brain of the rodents exposed to the stress (Moghaddam, 1993). Glutamate so released results in the activation of NMDA receptors (Nowak et al., 1995; Okano et al., 1995); linked with the nNOS via PSD95 (Brenman and Bredt, 1997). NMDA receptors activation exposes nNOS directly to the flux of $\mathrm{Ca}++$ entering the ion channel for the production of NO (Garthwaite et al., 1988; Liu et al., 2004). This is further supported by the fact that the large amount of the glutamate has been found in the CNS of the depression patients (Altamura et al., 1993; Levine et al., 2000; Mathis et al., 1988). Another mechanism suggested that the exposure to the 
immobilization stress results in the release of the pro-inflammatory cytokines such as IL- 1 and TNF- $\alpha$ in the brain of rodents exposed to immobilization stress (Wichers and Maes, 2002). IL-1 and TNF- $\alpha$ increases the expression of NF- $\kappa \beta$ pathway which is further responsible for the increase expression of iNOS (Cooke et al., 2001; Hua et al., 2008; Alexopoulos and Morimoto, 2011; Madrigal et al., 2002) which produces larger quantities of NO (Madrigal et al., 2002). Also it has been reported that the exposure to stressful conditions increased the expression of iNOS (Madrigal et al., 2001; Olivenza et al., 2000). Thus stress induced production of NO may either be due to the increased expression of nNOS or iNOS in the brain of the rodents exposed to immobilization stress.

Since the increased expression of the iNOS is followed by the activation of $N F-\kappa \beta$ pathway (Madrigal et al., 2002); therefore we checked the possible involvement of the NF- $\kappa \beta$ pathway in the compromised antidepressant effect of fluoxetie in the stressed mice. We administered the stressed mice with $\mathrm{NF}-\kappa \beta$ pathway inhibitor, PDTC (100 $\mathrm{mg} / \mathrm{kg}$, i.p.) alone and in combination with FLX (20 mg/kg, i.p.). It was found that PDTC $(100 \mathrm{mg} / \mathrm{kg}$, i.p.) reduced the immobility period of stressed mice significantly as compared to the vehicle treated stressed mice in both TST and FST as shown in fig.1 and fig.2. But the pretreatment with PDTC (100 mg/kg, i.p.) followed by the administration of the FLX (20 mg/kg, i.p.) to the stressed mice did not modulate the immobility period and the nitrite levels significantly as compared to the FLX (20 mg/kg, i.p.) treated stressed mice in the present study. Also the administration of PDTC (100 mg/kg, i.p.) in combination with FLX (20 mg/kg, i.p.) led to the death of all the 5 mice when they were tested in the FST after TST.

Therefore the present study suggested that pre-treatment with the PDTC did not significantly modulate the antidepressant effect of fluoxetine in stressed mice. However the increased levels of NO was responsible for the compromised antidepressant effect of the fluoxetine in the stressed mice. Therefore to determine the possible role of NOS and $\mathrm{sGC}$, we administered the stressed mice with the inhibitor of NOS and sGC, i.e. MB (100 mg/kg, i.p.) alone and in combination with in combination with FLX (20 $\mathrm{mg} / \mathrm{kg}$, i.p.).

Administration of $\mathrm{MB}(100 \mathrm{mg} / \mathrm{kg}$, i.p.) to the stressed mice significantly reduced the immobility period of stressed mice significantly as compared to the vehicle treated stressed mice in both TST and FST as shown in fig.1 and 2. Also the pre-treatment of stressed mice with $\mathrm{MB}(100 \mathrm{mg} / \mathrm{kg}$, i.p.) followed by the administration of FLX (20 mg/kg, i.p.) reduced the immobility period in FST and nitrite levels of the stressed mice significantly as compared to the vehicle and FLX (20 mg/kg, i.p.) treated stressed mice as shown in fig. 2 and 3. Also it has been reported that the MB exerted antidepressant effect (Savegnago et al., 2008) in the stressed mice. The results of the present study showed that MB (100 mg/kg, i.p.) significantly modulate the antidepressant effect of FLX (20 mg/kg, i.p.) in stressed mice. Therefore it has been suggested that the immobilization stress of $2 \mathrm{hrs}$ increased the production of $\mathrm{NO}$ in the brain of the mice exposed to the immobilization and NO further stimulate the enzyme sGC responsible for the production of cGMP (Paul and Ekambaram, 2011; Moncada and Higgs, 2006). cGMP is known to produce the depressive effect by influencing the 5-HT transporters (Miller and Hoffman, 1994). cGMP mediated enhancement of 5-HT transporters results in the reduction of the 5-HT levels (Sezal and Walia, 2015). Therefore the combine administration of the MB (100 mg/kg, i.p.) and FLX (20 mg/kg, i.p.) to the stressed mice potentiated the antidepressant effect of FLX (20 mg/kg, i.p.) in stressed mice.

\section{CONCLUSION}

It has been concluded that the stress mediated increased production of NO plays a key role in the compromised antidepressant effect of the fluoxetine in stressed mice. Immobilization stress results in the increased production of NO, which stimulate the enzyme sGC, which further increase the production of cGMP and cGMP is known to alter the level of 5HT by influencing 5-HT transporters. Thus NO-cGMP pathway plays a key role in the compromise antidepressant effect of fluoxetine in stressed mice.

\section{Financial support and sponsorship: Nil.}

Conflict of Interests: There are no conflicts of interest.

\section{REFERENCES}

Alexopoulos GS, Morimoto SS. The inflammation hypothesis in geriatric depression. Int J Ger Psychiatry. 2011; 26(11): 1109-18.

Altamura CA, Mauri MC, Ferrara A, Moro AR, D'Andrea G, Zamberlan F. Plasma and platelet excitatory amino acids in psychiatric disorders. Am J Psychiatry. 1993; 150: 1731-33.

Bohus B, Koolhaas JM, Heijnen CJ, de Boer O. Immunological responses to social stress: dependence on social environment and coping abilities. Neuropsychobiol. 1993; 28(1-2): pp 95-9.

Brenman JE, Bredt DS. Synaptic signaling by nitric oxide. Curr Opin Neurobiol. 1997; 7: 374-8.

Caspi A, Sugden K, Moffitt TE, Taylor A, Craig IW, Harrington H, McClay J, Mill J, Martin J, Braithwaite A, Poulton R. Influence of life stress on depression: moderation by a polymorphism in the 5-HT gene. Sci. 2003; 301: 386-9.

Cheah JH, Kim SF, Hester LD, Clancy KW, Patterson SE, Papadopoulos V, Snyder SH. NMDA Receptor-Nitric Oxide Transmission Mediates Neuronal Iron Homeostasis via the GTPase Dexras. Neuron. 2006; 51(4): 431-40.

Conti AC, Cryan JF, Dalvi A, Lucki I, Blendy JA. cAMP Response Element-Binding Protein Is Essential for the Upregulation of Brain-Derived Neurotrophic Factor Transcription, But Not the Behavioral or Endocrine Responses to Antidepressant Drugs. J Neurosci. 2002; 22(8): 3262.

Cooke EL, Uings IJ, Xia CL, Woo P, Ray KP. Functional analysis of the interleukin-1-receptor-associated kinase (IRAK-1) in interleukin-1 betastimulated nuclear factor kappa B (NF-kappa B) pathway activation: IRAK-1 associates with the NF-kappa B essential modulator (NEMO) upon receptor stimulation. Biochem J. 2001; 359(2): 403-10.

Cryan JF, Mombereau C, Vassout A. The tail suspension test as a model for assessing antidepressant activity: review of pharmacological and genetic studies in mice. Neurosci Biobehav Rev. 2005a; 29: 571.

Cryan JF, Valentino RJ, Lucki I. Assessing substrates underlying the behavioral effects of antidepressants using the modified rat forced swimming test. Neurosci Biobehav Rev 2005b; 29:547-69.

Conti AC, Cryan JF, Dalvi A, Lucki I, Blendy JA. cAMP Response Element-Binding Protein Is Essential for the Upregulation of Brain-Derived Neurotrophic Factor Transcription, But Not the Behavioral or Endocrine Responses to Antidepressant Drugs. J Neurosci 2002;22(8):3262. 
Garthwaite J, Charles SL, Chess-Williams R. Endothelium-derived relaxing factor release on activation of NMDA receptors suggests role as intercellular messenger in the brain. Nature. 1988; 336: 385-8.

Gilhotra N, Dhingra D. Thymoquinone produced antianxiety-like effects in mice through modulation of GABA and NO levels. Pharmacol Rep. 2011; 63(3): 660-9.

Gilhotra N, Jain H, Dhingra D. Differential effects of nitric oxide synthase inhibitors on anxiety in unstressed and stressed mice. Ind J Exp Biol. 2010; 48(4): 365-72.

Hyase T. Depression- related anhedonic behaviors caused by the immobilization stress: a comparison with nicotine -induced depression like behavioral alterations and effects of nicotine and / or "antidepressant" drugs. J Toxicol Sci 2011;36(1):31-41.

Hua Y, Huang XY, Zhou L, Zhou QG, Hu Y, Luo CX, Li F, Zhu DY. DETA/NONOate, a nitric oxide donor, produces antidepressant effects by promoting hippocampal neurogenesis. Psychopharmacol. 2008; 200: 231-42.

Kaehler ST, Singewald N, Sinner C, Philippu A. Nitric oxide modulates the release of serotonin in the rat hypothalamus. Brain Res. 1999; 835: 346-9.

Klamer D, Engel JA, Svensson L. Phencyclidine-Induced Behaviour in Mice Prevented by Methylene Blue. Basic Clin Pharmacol Toxicol. 2004; 94(2): 65-72.

Konstandi M, Johnson E, Lang MA, Malamas M, Marselos M Noradrenaline, dopamine, serotonin: different effects of psychological stress on brain biogenic amines in mice and rats. Pharmacol Res. 2000; 41: 341-6.

Kuhn DM, Arthur REJ. Inactivation of brain tryptophan hydroxylase by nitric oxide. J Neurochem. 1996; 67: 1072-7.

Levine J, Panchalingam K, Rapoport A, Gershon S, McClure RJ, Pettegrew JW. Increased cerebrospinal fluid glutamine levels in depressed patients. Biol Psychiatry. 2000; 47: 586-93.

Liu CY, Xie DP, Liu JZ. Microinjection of glutamate into dorsal motor nucleus of the vagus excites gallbladder motility through NMDA receptor - nitric oxide - cGMP pathway. Neurogastroenterol Motil. 2004; 16: $347-53$

Madrigal JL, Hurtado O, Moro MA, Lizasoain I, Lorenzo P, Castrillo A, Boscá L, Leza JC. The increase in TNF-alpha levels is implicated in NF-kappaB activation and inducible nitric oxide synthase expression in brain cortex after immobilization stress. Neuropsychopharmacol. 2002; 26(2): 155-63.

Madrigal JL, Moro MA, Lizasoain I, Lorenzo P, Castrillo A, Boscá $\mathrm{L}$, Leza JC. Inducible nitric oxide synthase expression in brain cortex after acute restraint stress is regulated by nuclear factor kappaB-mediated mechanisms. J Neurochem. 2001; 76: 532-8.

Maj J, Rogoz Z, Skuza G, Sowińska H. The effect of CGP37849 and CGP 39551, competitive NMDA receptor antagonists, in the forced swimming test. Pol J Pharmacol. 1992; 44: 337-46.

Mathis R, Schmitt L, Benatia M, Granier F, Ghisolfi J, Moron P. Plasma amino acid disturbances and depression. Encephale. 1988; 14: 77-82.

McEwen BS. Allostasis and allostatic load: implications for neuropsychopharmacology. Neuropsychopharmacol. 2000; 22: 108-24.

McIntyre DC, Kent P, Hayley S, Merali Z, Anisman H. Influence of psychogenic and neurogenic stressors on neuroendocrine and central monoamine activity in fast and slow kindling rats. Brain Res. 1999; 840: 65-74.

Mazzon E, Cuzzocrea, S. Role of TNF- $\alpha$ in ileum tight junction alteration in mouse model of restraint stress. Am J Physiol-Gastrointest Liver Physiol 2008;294(5);G1268-80.

Miller KJ, Hoffman BJ. Adenosine 4 Receptors Regulate Serotonin Transport via Nitric Oxide and cGMP. J Biol Chem. 1994; 269(44): 27351-6.

Moghaddam B. Stress preferenetially increases extraneuronal levels of excitatory amino acids in the prefrontal cortex: comparison to hippocampus and basal ganglia. J Neurochem. 1993; 60: 1650-57.

Moncada S, Higgs EA. The discovery of nitric oxide and its role in vascular biology. Br J Pharmacol. 2006; 147: S193-201.

Nowak G, Redmond A, McNamara M, Paul IA. Swim stress increases the potency of glycine at the $\mathrm{N}$-methyl- D-aspartate receptor complex. J Neurochem. 1995; 64: 925-7.

Okano K, Kuraishi Y, Satoh M. Effects of repeated cold stress on aversive responses produced by intrathecal excitatory amino acids in tars. Biol Pharm Bull. 1995; 18: 1602-4.

Olivenza R, Moro MA, Lizasoain I, Lorenzo P, Fernández AP, Rodrigo J, Boscá L, Leza JC. Chronic stress induces the expression of inducible nitric oxide synthase in rat brain cortex. J Neurochem. 2000; 74: 78591.
Paul V, Ekambaram P. Involvement of nitric oxide in learning \& memory processes. Indian J Med Res. 2011; 133: 471-8.

Paykel ES. Stress and affective disorders in humans. Semin Clin Neuropsychiatry. 2001; 6: 4-11.

Poleszak E, Wlaz P, Kedzierska E, Nieoczym D, Wyska E, Szymura-Oleksiak J, et al. Immobility stress induces depression-like behavior in the forced swim test in mice, effect of magnesium and imipramine. Pharmacol Rep. 2006; 58(5): 746-52.

Porsolt RD, Bertin A, Jalfre M. Behavioural despair in mice: a primary screening test for antidepressants. Arch Int Pharmacodyn Ther. 1977; 229: 327-36

Qiu Z, Parsons KL, Gruol DL. Interleukin-6 Selectively Enhances the Intracellular Calcium Response to NMDA in Developing CNS Neurons. J Neurosci. 1995; 75(10): 6686-99.

Rajkumar R, Mahesh R. The auspicious role of the 5-HT3 receptor in depression: a probable neuronal target. J Psychopharmacol. 2010; 24: 45569.

Rang HP, Dale MM, Ritter JM, et al, Pharmacology (6th ed) Philadelphia: Elsevier, 2007.

Savegnago L, Jesse CR, Pinto LG, Rocha JB, Barancelli DA, Nogueira CW, Zeni G. Diphenyl diselenide exerts antidepressant-like and anxiolytic-like effects in mice: involvement of L-arginine-nitric oxide-soluble guanylate cyclase pathway in its antidepressant-like action. Pharmacol Biochem Behav. 2008; 88(4): 418-26.

Sevgi S, O" zek M, Erog`lu L. L-NAME prevents anxietylike and depression-like behavior in rats exposed to restraint stress. Methods Find Exp Clin Pharmacol. 2006; 28(2): 95-9.

Sezal, Walia V. Review: Tinospora cordifolia in the treatment of depression. Pharmatutor. 2015; 3(12): 32-34.

Steru L, Chermat R, Thierry B, Simon P. The tail suspension test: a new method for screening antidepressants in mice. Psychopharmacol (Berl). 1985; 85: 367.

Straub VA, Grant J, O'Shea M, Benjamin PR. Modulation of Serotonergic Neurotransmission by Nitric Oxide. J Neurophysiol. 2007; 97: 1088-99.

Vollmayr B, Henn FA. Stress models of depression. Clin Neurosci Res. 2003; 3: 245-51.

Walia V, Sharma A, Gahlawat M, Dube O. Dual Role of Nitric Oxide in the Pathogenesis of Parkinson's Disease. J Pharm Sci Pharmacol. 2014; 1(4): 1-12.

Walia V. Influence of stress and fluoxetine on immobility period of mice in tail suspension test and forced swim test. Asian J Pharm Clin Res 2016a; $9(2): 1-4$

Walia V. Role of enzymes in the pathogenesis of depression. J Crit Rev. 2016b; 3(2): 1-6.

Wichers M, Maes M. The psychoneuroimmuno-pathophysiology of cytokine-induced depression in humans. Int J Neuropsychopharmacol. 2002; 5(4): 375-88.

Willner P, Towell A, Sampson D, Sophokleous S, Muscat R. Reduction of sucrose preference by chronic unpredictable mild stress, and its restoration by a tricyclic antidepressant. Psychopharmacol (Berl). 1987; 93: $358-64$.

Willner P. The validity of animal models of depression. Psychopharmacol (Berl). 1984; 83: 1.

Wong ML, Licinio J. From monoamines to genomic targets: a paradigm shift for drug discovery in depression. Nat Rev Drug Discov. 2004 3: 136-51.

Wuwongse S, Chang RCC, Law ACK. The putative neurodegenerative links between depression and Alzheimer's disease. Prog Neurobiol. 2010; 91: 362-75.

\section{How to cite this article:}

Walia V, Gilhotra N. Nitriergic Influence in the Compromised Antidepressant Effect of Fluoxetine in Stressed Mice. J App Pharm Sci, 2016; 6 (10): 092-097. 